\title{
A review on distribution and importance of wetlands in the perspective of India
}

\author{
Ashish Kumar Arya* \\ Department of Environmental Science, Graphic Era University, Dehradun (Uttarakhand), India \\ Kamal Kant Joshi \\ Department of Environmental Science, Graphic Era Hill University, Dehradun (Uttarakhand), \\ India \\ Archana Bachheti \\ Department of Environmental Science, Graphic Era University, Dehradun (Uttarakhand), India \\ Deepti \\ Department of Environmental Science, Graphic Era University, Dehradun (Uttarakhand), India \\ ${ }^{*}$ Corresponding author. Email: ashishtyagi.gkv@gmail.com
}

\section{How to Cite}

Arya A. K. et al. (2020). A review on distribution and importance of wetlands in the perspective of India. Journal of Applied and Natural Science, 12(4):710 - 720. https://doi.org/10.31018/jans.v12i4.2412

\section{Abstract}

Biodiversity is not equally distributed across the world. It depends on the type of various habitats and food availability. In these habitats, wetlands play an import role to increase the biodiversity of the particular area. Many studies have focused on various habitats to conserve biodiversity. However, the wetland studies are very few due to the lack of information on their distribution and importance. The present review focusses on the wetland status and their importance in India. India has vibrant and diverse wetland ecosystems that support immense biodiversity. The wetlands are unique habitats which provide ecological, social and economic values. However, rapid urbanization, industrialization and uncontrolled agricultural practices have pressurized to shrink the wetlands in India. The present paper highlights the wetland habitats in India with their geographical location, distribution, avian species diversity and their significance. The paper also discusses the growing threats like climate change, land-use change and agriculture/ municipal waste to the wetlands and the conservation efforts by Indian government policies, i.e. National Wetland Conservation Programme, National Environmental Policy, and National Plan for conservation of the aquatic ecosystem. In addition, on the basis of previous studies on wetlands, it is suggested that the role of stakeholders is very much responsible for wetland conservation.
\end{abstract}

Keywords: Avian biodiversity, Biodiversity, Conservation, Migratory birds, Wetlands

\section{INTRODUCTION}

Wetlands are one of the most productive ecosystems of our natural environment (Ghermandi et al., 2010). They are highly supported by many creatures, including birds. Wetlands cover 15.26 million hectares of space in India (Prasad et al., 2002; SAC, 2011). Generally, wetlands are shallow water lands which support the growth of various flora and fauna ( reptiles, amphibians, fish and other invertebrates (Mitsch and Gosselink, 2000). It is reported that wetlands are suitable habitat for avian species. Total 1340 bird species have been recorded in India (Ali and Ripley, 1987; Grimmett et al., 2016) with 38 endemic species (Praveen et al., 2016). Of the total, about 310 species are considered as wetland birds (Kumar et al., 2005). The diversity of any wetland depends upon the water quality and the vegetation around the wetland for the survival of the species (Buckton, 2007).
The wetlands are a very important part of human civilization, according to ancient literature, much human civilization developed near the riverine system or wetland areas. They are fulfilling many crucial needs like water, protein production, water purification, biodiversity, flood control, recreation and research-education etc. Wetlands have great cultural, social, ecological and economic values (Ramachandra et al., 2002). Wetlands in India are degrading very fast. In India, many reasons have been identified which are responsible for wetland degradation such as unsustainable agriculture practice, construction of human settlement around the wetlands, cattle grazing and the construction of dams, respectively. In addition, increasing human population, unsustainable development, and lack of awareness are responsible causes to decline the wetland areas (Ramachandra et al., 2002). Natural calamities are also accountable for the wetland degradation reported (Bennett et al., 2018). Sometimes wet- 
lands areas are used for crop cultivation and that way change into their habitat effects on biodiversity. At the Global level, habitat destruction via land-use change has been identified as one of the causes responsible for loss of biodiversity (Butchart et al. 2010, Sala et al. 2000). The present review article focuses on the distribution of wetlands in India, importance and strategy for conservation of wetlands.

Wetlands encompass a wide array of "wetlands" also called marshes, bogs, swamps, fens, pocosins, and other names" (Tiner, 1999). Wetlands are neither truly aquatic nor terrestrial; generally, it depends on seasonal variability. This transitional nature of wetland creates complexity to delineate the boundaries of wetlands. On the other hand, it enhances the diversity with reference to flora and fauna of that area due to their geographical location and habitat characteristics. Based on multifaceted observations and diverse objective and orientation, different individuals, institutions and agencies have defined wetlands in their own ways. In addition, many countries also defined wetlands as per their domestic legislation (MOEF, 2007). Ramsar Convention is only one International agreement signed in 1971 to make the action plans on a national and international level for conservation of the wetlands and their resources (Bassi et al., 2014). In this convention, a total of 2300 Ramsar sites were introduced in the World (Ramsar, 2013) and were focused for their conservation.

As per the Ramsar Convention, (article 1.1) the wetlands are defined as "Areas of the marsh, fen, peatland or water, whether natural or artificial, permanent or temporary, with water that is static or flowing, fresh, brackish or salt, including areas of marine water the depth of which at low tide does not exceed six meters" (Ramsar Convention, 1971, Article 1.1).

\section{WETLANDS CLASSIFICATION}

In 1979, the US Fish and Wildlife Service published and adopted a classification of wetlands and deepwater habitats of the United States (Cowardin et al., 1979). The wetlands are categorized on the basis of the hydrological, ecological and geological condition of the area. Accordingly, on the basis of this classification, wetlands are divided into five major categories (Table 1).
Table 1. Classification system of wetlands.

\begin{tabular}{|c|c|c|}
\hline S. No. & $\begin{array}{l}\text { Wetland } \\
\text { Category }\end{array}$ & Type of Wetland \\
\hline 1. & Estuarine & $\begin{array}{l}\text { Deltas, Tidal marshes and } \\
\text { Mangrove swamps }\end{array}$ \\
\hline 2. & Lacustrine & Natural Lakes \\
\hline 3. & Marine & Coastal wetland \\
\hline 4. & Riverine & River and Stream \\
\hline 5. & Palustarine & $\begin{array}{l}\text { Marshy - Marshes, Swamps } \\
\text { and Bogs }\end{array}$ \\
\hline
\end{tabular}

Source: Cowardin et al. (1979)

\section{CLASSIFICATION OF WETLANDS IN INDIA}

The area of wetlands is widely distributed in India ranging from Himalayan region to Deccan knap. India has a different type of climatic and topographic conditions to be responsible for a high diversity of flora and fauna (Prasad et al., 2002). National Wetland Atlas (2011) classified the Indian wetlands in three levels, i.e. Level 1 to Level 3. Level-1 wetlands are divided into two classes- Inland and coastal areas respectively, and Level-2 types are categorized into natural and man-made categories. However, in Level 3, types of wetlands are natural and man-made wetlands and these are further classified into 19 subcategories on the basis of temporal vegetation, climatic and topographic conditions (Table 2).

\section{DISTRIBUTION OF WETLANDS IN INDIA}

Wetlands are vital for human survival. At a global level, wetlands cover a total area of 12.1 million $\mathrm{km}^{2}$ and account for $40.6 \%$ of the total global ecosystem services (ES) value (Costanza et al., 2014; Gardner and Finlayson, 2018). However, India has various types of water resources in the form of rivers, streams and coastal areas. India has 757,060 wetlands covering about 15.26 million hectares area, which is around $4.63 \%$ of the total geographical area of the country. Out of these, 45,658 are Inland natural and 142,812 Inland man-made wetlands (Table 3; Fig-1). India has a very large area of coastal wetlands, including the 10,204 natural and 2829 man-made coastal wetlands (SAC, 2011). Inland wetlands cover an area of 10.56 million hectares $(69.23 \%)$ and area under coastal wetlands is 4.14 million hectares $(27.13 \%)$. The small

Table 2. Indian wetland classification (Source: National Wetland Atlas, 2011).

\begin{tabular}{|c|c|c|c|c|}
\hline Level 1 & \multicolumn{2}{|c|}{ Inland wetland } & \multicolumn{2}{|c|}{ Coastal Wetlands } \\
\hline Level 2 & Natural & Manmade & Natural & Manmade \\
\hline Level 3 & $\begin{array}{l}\text { Lake } \\
\text { Rivers } \\
\text { Ox-Bow lake } \\
\text { High altitude wetland } \\
\text { Riverian Wetland }\end{array}$ & $\begin{array}{l}\text { Reservoir/Barrage } \\
\text { Tank/Pond } \\
\text { Water Logged } \\
\text { Salt pan }\end{array}$ & $\begin{array}{l}\text { Lagoon } \\
\text { Creek } \\
\text { Sand/Beach } \\
\text { Salt Marsh } \\
\text { Mangrove } \\
\text { Coral Reef }\end{array}$ & $\begin{array}{l}\text { Salt Pan } \\
\text { Aquaculture pond }\end{array}$ \\
\hline
\end{tabular}


types wetland ( $<2.25$ ha) cover about 3.64 percent of land area ( 0.56 million hectares) and it is assumed that each is about of one ha (SAC,2011).

As per the Indian wetland classification, India has a total of 75,7060 wetlands which are distributed in different states of India (National Wetland Atlas, 2011). State-wise numbers of wetland are shown in Fig 2. However, the Indian Himalayan Region has shown less number of wetlands areas as compared to the plain areas ( Fig 2). The records indicate that total numbers of Inland (natural) wetlands are 45658, manmade is 142812 , coastal wetland (natural) are 10204 , and man-made are 2829 respectively. Similarly, inland wetlands (natural and man-made) area about $69.23 \%$ and coastal wetlands (natural and man-made) have $27.13 \%$ and rest $3.64 \%$ of wetlands are less in 2.25 ha respectively.

\section{RAMSAR SITES IN INDIA}

The Ramsar Convention was not only a global agreement to the conservation of wetland but also encouraged the sustainable utilization of wetland as a re- source. In addition, give attention to the scientific community for their basic ecological functions of wetlands and their economic, social, aesthetic, and scientific significances (Sarkar, 2011). India signed a Ramsar convention on $1^{\text {st }}$ February 1982 and at present India has 41 Ramsar sites (Table 4) which cover about 1,071,861 hectares area (Ramsar, 2013; MoEFaCC, 2020a; MoEFaCC, 2020b).

\section{IMPORTANCE OF WETLANDS}

Wetlands are generally used in many ways, mainly for irrigation services, fisheries, and recreation activities. They play a key role to maintain the ecological balance. Wetlands provide many ecological services like carbon sequestration, flood control, recharge underground water level and maintenance to the biodiversity (Turner et al., 2000). Wetlands indicate a great ecological value to provide the many services and products for human beings (Prasad et al., 2002). Across the world, wetland covers about $40.6 \%$ of the total global ecosystem services value (Costanza et al., 2014). However, in India, wetlands cover $4.63 \%$ area

Table 3. Showing area-wise wetlands in India.

\begin{tabular}{|c|c|c|c|c|}
\hline Sr. No. & Wetland Category & $\begin{array}{l}\text { Number of } \\
\text { wetlands }\end{array}$ & $\begin{array}{l}\text { Total wetland } \\
\text { area (ha) }\end{array}$ & $\begin{array}{l}\% \text { of wetland } \\
\text { area }\end{array}$ \\
\hline 1 & Lake/Pond & 11740 & 729532 & 4.78 \\
\hline 2 & Ox-bow lake/Cut-off meander & 4673 & 104124 & 0.68 \\
\hline 3 & High altitude wetland & 2707 & 124253 & 0.81 \\
\hline 4 & Riverine wetland & 2834 & 91682 & 0.60 \\
\hline 5 & Waterlogged & 11957 & 315091 & 2.06 \\
\hline \multirow[t]{2}{*}{6} & River/Stream & 11747 & 5258385 & 34.46 \\
\hline & Inland Wetlands -Man-made & & & \\
\hline 7 & Reservoir/Barrage & 14894 & 2481987 & 16.26 \\
\hline 8 & Tank/Pond & 122370 & 1310443 & 8.59 \\
\hline 9 & Waterlogged & 5488 & 135704 & 0.89 \\
\hline \multirow[t]{3}{*}{10} & Salt pan & 60 & 13698 & 0.09 \\
\hline & Total - Inland & 188470 & 10564899 & 69.23 \\
\hline & Coastal Wetlands - Natural & & & \\
\hline 11 & Lagoon & 178 & 246044 & 1.61 \\
\hline 12 & Creek & 586 & 206698 & 1.35 \\
\hline 13 & Sand/Beach & 1353 & 63033 & 0.41 \\
\hline 14 & Intertidal mudflat & 2931 & 2413642 & 15.82 \\
\hline 15 & Salt Marsh & 744 & 161144 & 1.06 \\
\hline 16 & Mangrove & 3806 & 471407 & 3.09 \\
\hline \multirow[t]{2}{*}{17} & Coral Reef & 606 & 142003 & 0.93 \\
\hline & Coastal Wetlands - Man-made & & & \\
\hline 18 & Salt pan & 609 & 148913 & 0.98 \\
\hline \multirow[t]{5}{*}{19} & Aquaculture pond & 2220 & 287232 & 1.88 \\
\hline & Total - Coastal wetland & 13033 & 4140116 & 27.13 \\
\hline & Sub-Total & 201503 & 14705015 & 96.36 \\
\hline & Wetlands (<2.25 ha) & 555557 & 555557 & 3.64 \\
\hline & Total & 757060 & 15260572 & 100.00 \\
\hline
\end{tabular}




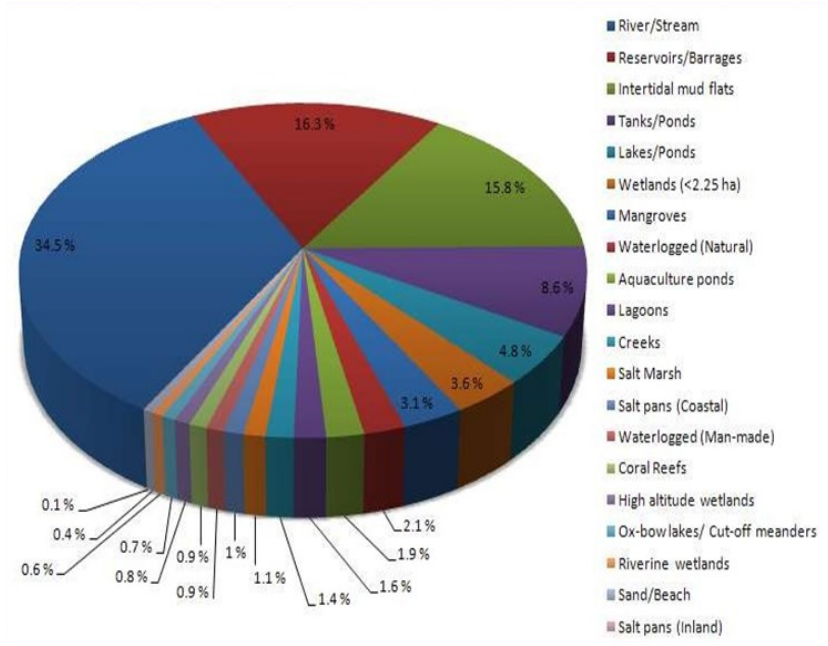

Fig. 1. Distribution of wetlands in India (Source : Ministry of Environment and Forests 2007; National Wetland Atlas, 2011).

of the total geographical area of Indian territory (SAC, 2011).

Multiple-use of water: Many types of wetlands, i.e. lake, reservoir, ponds, water tanks provide many types of water services like agricultural irrigation, domestic use, fish cultivation, flood control etc. Generally, collection of water into the concrete tank is known as a water tank, and use of this water in agriculture practices is called Tank irrigation. ). It has been reported that these irrigation water tanks play a vital role to conserve the soil and biodiversity (Balasubramanian and
Selvaraj, 2003). There are many techniques used in agriculture irrigation and out of these, the tank irrigation system is one of them and used in a different part of India.. In the southern part of India, farmers wildly use the tank irrigation system and contract the largest number of irrigation tanks (Palanisami et al., 2010) and cover about $60 \%$ area of tank irrigated land of the country. Similarly, some other states like Bihar, Uttar Pradesh and West Bengal used the traditional tank system for irrigation (Pant and Verma, 2010). These water tanks are also used for fisheries and domestic purposes (Kumar et al., 2013). India also has a large number of natural lakes. The lakes have been providing the different services like recreation, tourism activity, domestic water supply and groundwater recharge. Lakes are also supported to the high diversity of flora and fauna (Jain et al., 2007a, Jain et al., 2007b; Bhatt, 2015; Kumar, 2019).

Fish production: Wetland ecosystem is highly supportive to the fish production. The maximum fishes (about 66\%) are collected from the level I type of wetland (Inland water bodies), i.e. canals, rivers, ponds, water reservoirs and natural lakes. Fish production has continuously increased in India; total production increased by 9.04 million tonnes from 2012 to the 2013 year and about 12.59 million tonnes between the years 2017 to 2018 (Table 5). The State of Andhra Pradesh had the topmost position of the fish production with the $27 \%$ of total production followed by West Bengal, Gujarat, Orissa, Tamil Nadu and Uttar Pradesh respec-

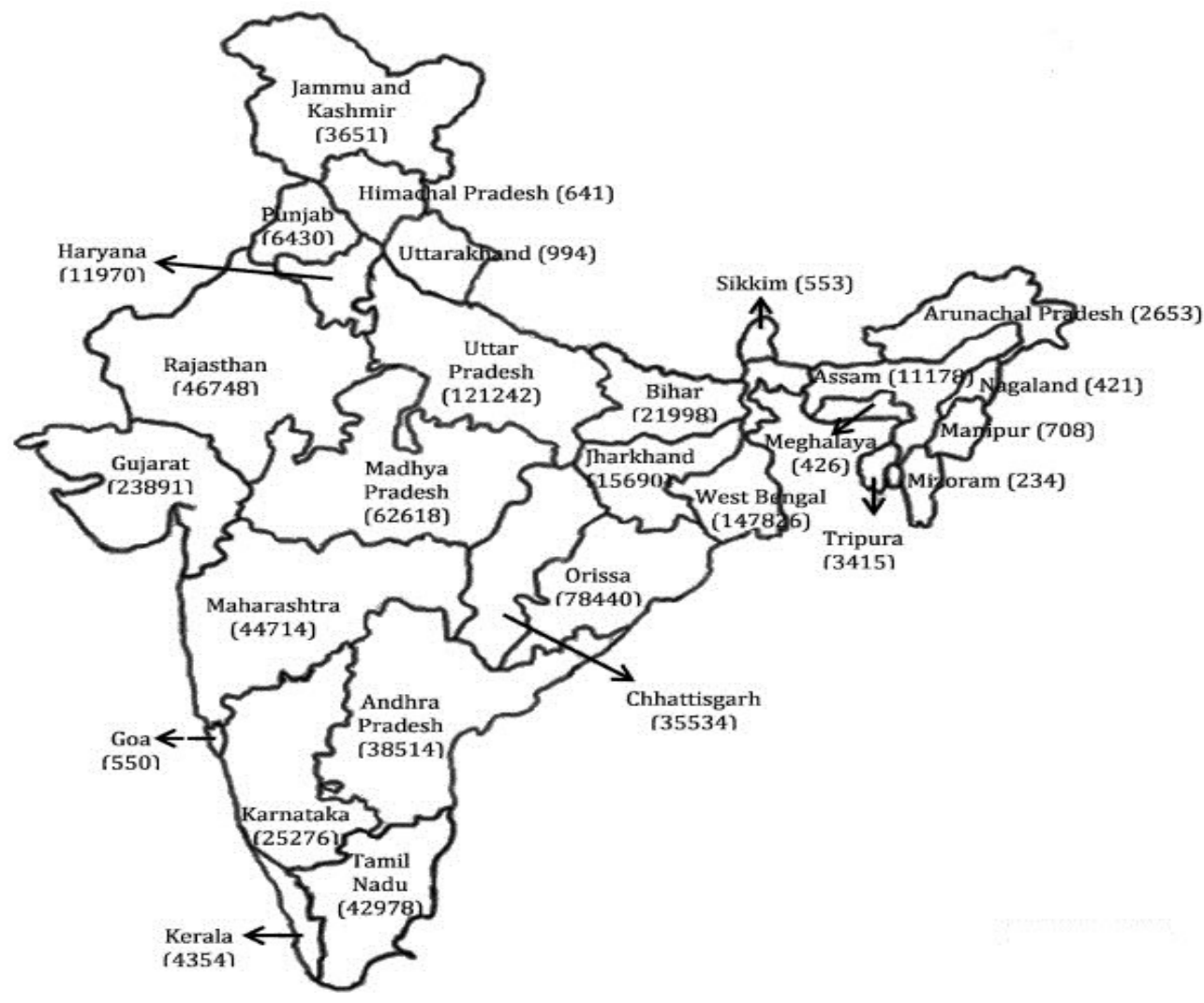

Fig. 2. State-wise wetlands in India (Source: SAC, 2011; Bassi et al., 2014). 
Table 4. Showing Ramsar wetlands sites in India.

\begin{tabular}{|c|c|c|c|c|}
\hline S. No. & Wetland Sites & Location in state & Area (ha) & Declaration Date \\
\hline 1 & Asthamudi Wetland & Kerala & 614 & 19.8 .2002 \\
\hline 2 & Beas Conservation Reserve & Punjab & 64.289 & 26.9.2019 \\
\hline 3 & Bhitarkanika Mangroves & Orissa & 650 & 19.8.2002 \\
\hline 4 & Bhoj Wetlands & Madhya Pradesh & 32.01 & 19.8.2002 \\
\hline 5 & Chandertal Wetland & Himachal Pradesh & 0.49 & 8.11 .2005 \\
\hline 6 & Chilka Lake & Orissa & 1165 & 1.10 .1981 \\
\hline 7 & DeeporBeel & Assam & 40 & 19.8.2002 \\
\hline 8 & East Kolkata Wetlands & West Bengal & 125 & 19.8.2002 \\
\hline 9 & Harike Lake & Punjab & 41 & 23.3.1990 \\
\hline 10 & Hokera Wetland & Jammu and Kashmir & 13.75 & 8.11 .2005 \\
\hline 11 & Kanjli Lake & Punjab & 1.83 & 22.1.2002 \\
\hline 12 & Keoladeo Ghana NP & Rajasthan & 28.73 & 1.10 .1981 \\
\hline 13 & Keshopur-Miani Community Reserve & Punjab & 3.439 & 26.9.2019 \\
\hline 14 & Kolleru Lake & Andhra Pradesh & 901 & 19.8.2002 \\
\hline 15 & Loktak Lake & Manipur & 266 & 23.3.1990 \\
\hline 16 & Nalsarovar Bird Sanctuary & Gujarat & 120 & 24.09.2012 \\
\hline 17 & NandurMadhameshwar & Maharashtra & 14.37 & 21.6.2019 \\
\hline 18 & Nangal Wildlife Sanctuary & Punjab & 1.16 & 26.9.2019 \\
\hline 19 & Nawabganj Bird Sanctuary & Uttar Pradesh & 2.246 & 19.9.2019 \\
\hline 20 & Parvati Agra Bird Sanctuary & Uttar Pradesh & 7.22 & 2.12.2019 \\
\hline 21 & $\begin{array}{l}\text { Point Calimere Wildlife and Bird } \\
\text { Sanctuary }\end{array}$ & Tamil Nadu & 385 & 19.8.2002 \\
\hline 22 & Pong Dam Lake & Himachal Pradesh & 156.62 & 19.8.2002 \\
\hline 23 & Renuka Wetland & Himachal Pradesh & 0.2 & 8.11 .2005 \\
\hline 24 & Ropar Lake & Punjab & 13.65 & 22.1.2002 \\
\hline 25 & Rudrasagar Lake & Tripura & 2.4 & 8.11 .2005 \\
\hline 26 & Saman Bird Sanctuary & Uttar Pradesh & 52.63 & 2.12 .2019 \\
\hline 27 & Samaspur Bird Sanctuary & Uttar Pradesh & 79.94 & 3.10 .2019 \\
\hline 28 & Sambhar Lake & Rajasthan & 240 & 23.3.1990 \\
\hline 29 & Sandi Bird Sanctuary & Uttar Pradesh & 30.85 & 26.9.2019 \\
\hline 30 & SarsaiNawarJheel & Uttar Pradesh & 16.13 & 19.9.2019 \\
\hline 31 & Sasthamkotta Lake & Kerala & 3.73 & 19.8.2002 \\
\hline 32 & Sunderbans Wetland & West Bengal & 4230 & 30.1 .2019 \\
\hline 33 & Surinsar-Mansar Lakes & Jammu and Kashmir & 3.5 & 8.11 .2005 \\
\hline 34 & Tsomoriri Lake & Jammu and Kashmir & 120 & 19.8.2002 \\
\hline 35 & $\begin{array}{l}\text { Upper Ganga River } \\
\text { (Brijghat to Narora Stretch) }\end{array}$ & Uttar Pradesh & 265.9 & 8.11 .2005 \\
\hline 36 & VembanadKol Wetland & Kerala & 1512.5 & 19.8.2002 \\
\hline 37 & Wular Lake & Jammu and Kashmir & 189 & 23.3.1990 \\
\hline 38 & Asan Conservation Reserve & Uttarakhand & 444.4 & 21.7.2020 \\
\hline 39 & Kabartal Wetland & Bihar & 2620 & 21.7.2020 \\
\hline 40 & Lonar Lake & Maharashtra & 427 & 22.7.2020 \\
\hline 41 & Sur Sarovar & Uttar Pradesh & 431 & 22.8.2020 \\
\hline
\end{tabular}

Source: Ministry of Environment, Forests and Climate Change (2020a and 2020b).

tively (Ministry of Fisheries, Animal Husbandry and Dairying, 2017). Fisheries contribute for $1.07 \%$ of total Gross Domestic Product (GDP) of the country and $5.23 \%$ of total agricultural GDP (Ministry of Fisheries, Animal Husbandry and Dairying, 2018).
Carbon sequestration: Wetlands play an important role in $\mathrm{C}$ sink to climate regulation. Different types of wetland structures like mangroves, swamps and marshes play a significant role in the carbon cycle. Wetlands store carbon as the biomass of aquatic flora, 
Arya A. K. et al. / J. Appl. \& Nat. Sci. 12(4): 710 - 720 (2020)

Table 5. Fish production in India (2012-2018).

\begin{tabular}{llll}
\hline Years & Total (million tonne) & In-land contribution (\%) & Marine contribution (\%) \\
\hline $2012-13$ & 9.04 & 63.26 & 36.74 \\
$2013-14$ & 9.58 & 64.06 & 35.94 \\
$2014-15$ & 10.26 & 65.21 & 34.79 \\
$2015-16$ & 10.76 & 66.55 & 33.45 \\
$2016-17$ & 11.43 & 68.21 & 31.71 \\
$2017-18$ & 12.59 & 70.71 & 29.29 \\
\hline
\end{tabular}

Source: Ministry of Fisheries, Animal Husbandry and Dairying (2018).

fauna and microbes. Some amount of carbon enters into the wetlands through sedimentation and as dissolved form from the surface and groundwater (Wylynko, 1999). Wetlands are the largest source of the methane $\left(\mathrm{CH}_{4}\right)$ emission; they have contributed $40 \%$ methane $\left(\mathrm{CH}_{4}\right)$ emissions of the total emission in the world (Pant et al., 2003; Jain et al., 2007). Wetlands soil contain a very heavy amount of carbon in compression to vegetation structure. We can reserve them to sink atmospheric $\mathrm{CO}_{2}$ through there restoration of wetlands (Lal, 2008; Kathiresan and Thakur, 2008). In India, coastal wetlands play a significant role in carbon sequestration. Wetlands have the ability of carbon sequestration in being considered in greenhouse gases emission (Villa and Bernal, 2018).

Pollution control: Wetland areas are helpful to reduce the pollution from the water. Some studies have mentioned that wetlands have been generally used as a wastewater treatment plant through Multiple free water surface flow constructed wetlands technique around the world in 1950 (Kickuth. 1984). Multiple free water surface flow constructed wetlands technique are man-made ponds or tanks for impounding run-off, which function as the wastewater treatment plant. They are designed for sewage treatment in remote, underdeveloped rural areas (llyas and Masih 2017) People have used the wetlands as a water purifier. Pollution control and water quality enhancement are one of the most important functions of the wetlands has been reported in the studies (Mitsch and Gosselink, 2000, 2007; Blackwell et al., 2002; Verhoeven et al., 2006; Han et al. 2017)). Various studies have shown the usefulness of wetlands in pollution abatement in India ( Kaur et al., 2012; Mondal et al., 2018). Some wetland potent plant species like Typha, Phragmites, Eichhornia, Azolla and Lemna are identified as a heavy metal removal from the wetlands (Rai, 2008; Ali et al., 2020)

Flood control: Most of the wetlands have the capacity to store the extra water or flood water for protecting the downstream area by the flood. Wetlands to maintain the flow of the downstream maintain the water quality and enhance the biotic productivity of the aquatic flora and fauna (Talbot et al., 2018). This function of wetlands is most important especially in the urban area because off in this area divided the wetland in many branches to fulfil the requirements of residential, commercial, and industrial activities, Due to these activities have enhance the rate and volume of surface water run-off and the potential to flood damage (Ramachandra et al., 2002). During the flood condition, they have suspended solids and nutrients. Thus, the stream flowing from the wetland transport suspend solid nutrient flow directly into the river. These nutrients reach out to the agricultural field by irrigation water from the river (Boyd and Banzhaf, 2007). Wetlands play a key role in flood control. They help to reduce the impacts of flooding by absorbing water and reducing the speed at which floodwater flows (Bassi et al., 2014). The wetlands play an important role in the hydrological cycle also, influencing groundwater recharge, low flows, evaporation and floods (PattisonWilliams et al., 2018).

Biodiversity hotspots: A biodiversity hotspot is a biogeographic region with significant levels of biodiversity. Wetlands are one of the most important habitats to supporting the species diversity. Different types of invertebrates and vertebrates spend their life cycle around the wetlands because of a suitable environment and food availability. These habitats support the food chain also (Juliano and Simonovic, 1999). India has a large number of freshwater bodies such as lakes and rivers. They have support to mega diversity of biotic communities. A total number of aquatic plant species more than 1200 have valuable support as a food resource (Prasad et al., 2002; Hidding et al., 2010; Wood et al., 2012). The freshwater ecosystem of southern India especially in Western Ghats region has very rich biodiversity. Loktak Lake is the largest natural water body which is situated in Manipur state of North East region (India). This freshwater lake supports rich avian biodiversity (Sharma, 2009a). Loktak Lake is famous for its very unique types of vegetation. Generally, it is called Phumdi. In addition, 75 phytoplankton species, 120 rotifers species and one endangered Manipur brow-antlered deer were reported from the LoktakLake (Sharma, 2009b). About 290 fish species, 77 molluscs, 135 amphibians and 608 aquatic plant species have been reported from the North East region (India). Many species of fishes, molluscs and aquatic plants are endemic in theWestern Ghats (Molur et al., 2011). The value of biodiversity also enhances through the constructions of the artificial wetlands, because this additional wetland habitat provides additional food 
resources to the aquatic bird species (Ghermandi et al., 2010).

Wetland areas provide a unique habitat for many water birds and water migratory bird species, it. Some studies in India (Saini et al., 2017) have been reported wetland provides good shelter, food, and enhance the waterbird diversity. In India, many wetlands areas such as Bharthpur wildlife sanctuary, Rajasthan, coastal areas of Gujarat and many more wetlands host the thousands migratory birds come from western and European countries (Agarwal, 2011). Many types of water migratory birds have migrated in India as winter visitors through the different flyways. Studies (Bhatt, 2015, Saini et al., 2017,) shows in Haridwar Bheemgoda wetland in Uttarakhand also provides a suitable habitat, food availability. The same observation was reported in Bheemgoda and Misserpuer wetlands, Haridwar (Arya et al., 2019). Different types of avian species including ducks, geese, falcons and warblers come in India from three flyways. Approximate 370 migratory avian species comes in Indian sub -continent from Pale Acrtic, Russia and Different parts of Europe. Out of these, 310 are water migratory birds reported in different parts of Uttarakhand wetlands like Misserpur, Bheemgoda wetlands (Bhatt, 2015) and Asan wetland ( Kumar, 2019).

\section{GROWING THREATS TO WETLANDS}

Globally, many wetlands have been exploited and are not utilized sustainably (Mitsch and Gossilink, 2000; Rebelo et al., 2019), and it has been estimated that about $35 \%$ loss in the global wetland since 1970 (Ramsar Convention on Wetlands, 2018). They are under great pressure in the Asiatic region. This region lost a very large area of wetlands per year due to agricultural and developmental activities (McAllister et al., 2001). Due to the degradation of the wetlands, many wetland habitat species like birds $(21 \%)$, mammals $(37 \%)$ and freshwater fishes $(20 \%)$ have become threatened (MEA, 2005). In addition, loss of the wetland area results in an impact on the important functioning of the wetlands (Zedler and Kercher, 2005). Further requirements of water and other resources of wetlands have placed great pressure on the ecosystem, then they had shown a direct impact on species diversity and population (Molur et al., 2011).

Landuse changes: The improper management of wetlands, lack of implementation of conservation plans, increase in the pollution, and rapidly increase the requirements of water by local peoples are also affected the water bodies and pushing these good eco -balancers to extinction (Indian National Trust for Art and Cultural Heritage, 1998). Maximum areas of the major river basins in India have changed into different land use pattern. They have increased into the agricultural field and non-agricultural area have converted into flood plain areas, forest, and grassland area and associated freshwater ecosystems fulfil the food re- quirements of the population (Zhao et al., 2006). Similarly, in the Bengaluru region, 66 wetlands have vanished due to increases the urbanization (Ramachandra and Kumar, 2008). In India, several development projects like irrigation and water supply have changed the patterns of water inflows and water spread areas of many natural water bodies. Total 1276 irrigation projects have been completed in India (Central Water Commission, 2010).

Urbanization has shown a significant impact on the structure and function of wetlands, through modifying the hydrological and sedimentation structure and chemical pollutants. Impact of urbanization is also an effect on natural wetlands in the different cities of India. Some previous studies have mentioned that 264 water bodies were identified in Delhi as the National Capital Territory (NCT) while 232 water bodies have almost destroyed due to lack of conservation measures (Khandekar, 2011). The population of India has increased very rapidly. From 1951 to 2020, the population of India has increased from 0.4 billion to 1.4 billion with 24\% growth rate. During 1901 to 1990 , urban centres are double and the urban population increased significantly (Bassi and Kumar, 2012, Pandey et al., 2015). Such population pressure and development activities in India are responsible for the land use pattern, and habitats are degraded rapidly and their adverse impact on avian diversity also (Grumbine and Pandit 2013).

Agricultural, municipal and industrial pollution: In India, maximum water bodies such as rivers, lakes and streams have been degraded due to unsustainable agriculture practices. In addition, using of chemicals as pesticide and fertilizer in agriculture fields, discharge of untreated industrial and municipal waste into the water bodies are responsible for the degradation of natural water resources (Liu and Diamond, 2005; Hagirath et al., 2011; Bassi, 2014). Nutrient contents encourage the algal growth, responsible for eutrophication of surface water bodies. Some studies had shown that 0.5 $\mathrm{mg} / \mathrm{l}$ of inorganic Nitrogen and $0.01 \mathrm{mg} / 1$ of organic Phosphorus in water usually stimulate unwanted algal growth in the surface water. Agricultural run-off is one of the major sources of non-point pollution to the Indian water bodies in Indo-Gangetic plains (Jain et al., 2007 (a), Jain et al., 2007 b)). The eutrophication can reduce the fish population in the Indian lakes and rivers (Verhoeven et al., 2006; Singh et al., 2018). Along with the agricultural run-off, untreated water also contributes to pollution into wetlands. Only $30 \%$ wastewater can be treated of Indian urban centres (Almuktar et al., 2018). According to the CPCB, there is a major gap between generation and treatment of wastewater in the urban area, and every day a huge amount of untreated wastewater or sewage is discharged into the nearest natural water bodies. It has been reported in the CPCB report in 2010 that such water bodies are situated near the urban areas are 
becoming saprobic and eutrophicated due to the water pollution. Indian agricultural systems are largely dependent on chemical pesticides and fertilizers. In India, $10-15 \%$ nutrients are added in the soil in the form of fertilizers than to touch with the surface water system (Indian Institute of Technology, 2011 Bassi, 2014). Global climate change: Wetlands are one of the largest sources of $\mathrm{CH}_{4}$. Methane is the major contributor of heat-trapping in the atmosphere, which leads to global warming. The rapidly increasing population of India causes a change in the landscape. The total precipitations have significantly decreased due to increases the greenhouse gases $\left(\mathrm{CO}_{2}, \mathrm{CH}_{4}\right.$ and $\mathrm{NO}_{x}$ gases) concentration in the atmosphere (Bates et al., 2008). It has been reported the climate change is one of the most important cause for the vanishing and transformation of wetland ecosystem (MEA, 2005, Colette et al., 2013).

\section{WETLAND MANAGEMENT POLICY IN INDIA}

The primary responsibility to manage all the natural sensitive wetland ecosystems in India comes under the Ministry of Environment and Forests (MoEF), Government of India. The Government makes the policies for the conservation of wetlands periodically; most of them are following to make conservation of wetlands.

Ramsar Convention: India has 41 Ramsar sites of wetland with international importance. India signed this agreement in February 1982. This Convention is only one global agreement to the conservation and sustainable utilization of wetlands (Sarkar, 2011).

National Wetland Conservation Programm (NWCP): This programme was firstly introduced in 1985 for the better conservation of wetlands in India. This programme was initiated for partially degraded wetlands (i.e. Renuka, Pong dam in Himachal, Whoolar, Hokersar in Jammu and Sambhar in Rajasthan). This programme was initiated for the conservation of wetland, to prevent further degradation of wetlands, to prevent the degradation of partially degraded wetlands (i.e. Roper, Nangal in Punjab and Loktak in Manipur) for the wisely use for the local communities and overall conservation of biodiversity (NWCP, 2009).

The Central Wetlands (Conservation and Management) Rules: These rules were introduced in 2010 for the better management and regulation of wetlands in India. Under these rules, a new Central Wetlands Regulatory Authority (CWRA) was constituted for the conservation and management of wetlands in India.. The wetlands rule 2010 has been amended in 2016 and 2017. The new Wetland (Conservation And Management) rules, 2017 replaced the Wetlands rule, 2010. It prohibits a range of activities in the wetlands of India. The amended on CWRA was applied on setup state Wetland Authority in every states and union territories of India. Experts of different fields like Wetland ecology, fisheries, hydrology and landscape ecology would be appointed by the state government to making the policies for conservation and management of wetlands. (Wetlands Conservation and Management Rules, 2017)

National Environment Policy, 2006: This policy recognized the importance of wetlands, and it made plans and policies for the conservation of wetland The policy aims at setting up a legally enforceable regulatory mechanism for identified valuable wetlands, to prevent their degradation and enhance their conservation. To formulate and implement the policy of sustainable tourism stagings through the partnership of stakeholders and the local communities. (MoEF, 2007).

National Plan for Conservation of Aquatic Ecosystems (NPCA): This plan was launched in the year 2015 to provide a better policy framework and support to the State Governments for management of wetlands. In this initiative, the two separate Centrally Sponsored Schemes (CSS), namely the National Wetlands Conservation Programme (NWCP) and the National Lake Conservation Plan (NLCP) are merged. The goal of the NPCA is to develop and maintain a network of healthy wetlands which may contribute to the human well-being through their diverse ecosystem services and biodiversity. In this regard, NPCA is to identify the wetlands location and, provide a national policy framework for conservation and sustainable management of wetlands. In this regards, NPCA envisages creating a network of well-conserved and sustainably managed wetlands which support biodiversity and provide their full range of ecosystem services. NPCA has involved State and Union territory administration for the conservation of wetlands through various anthropogenic activities and also supports in national capacity building programmes for strengthening the capacity of wetlands managers and stakeholders for effective management of wetlands (NPCA, 2019).

\section{Conclusion}

It was concluded that wetlands in India are one of the most diverse and important ecosystems due to their geographical and climatic conditions. They have played an important role to maintain the hydrological cycle and supporting large diversity of different types of flora, fauna and microbes. Wetlands have provided suitable habitats of different species of avifauna. They also have provided many types of services such as water supply, irrigation and freshwater fisheries. Wetlands have played a vital role to recharge the groundwater, control of flood, carbon sequestration and pollution control. In India, many wetlands or lakes, i.e. Nainital lake, Vollar, Loktak, and Chilka etc. have anthropogenic pressures including land-use changes, pollution from industries, encroachments and overexploitation of their natural resources. Thus, in the present scenario, it is suggested more attention is required to prepare better conservation strategies for the wetland ecosystems. However, government policies like the announcement of any wetland as a protected 
area are not sufficient to protect the wetlands. Along with the strict implementation of Government policies, education awareness programmes, and the role of local participation will be appreciable to conserve the wetland biodiversity.

\section{ACKNOWLEDGEMENTS}

I thank to Head of the Department, Department of Environmental Science, Graphic Era University, Dehradun for providing the facilities during writing of this review article. I am also thankful to Prof. Dinesh Bhatt, Head of the Department, Department of Zoology and Environmental Science, Gurukula Kangri University, Haridwar for valuable suggestions from time to time.

\section{Conflict of interests}

The authors declare that they have no conflict of interests.

\section{REFERENCES}

1. Agarwal, M. (2011). Migratory birds in India: Migratory birds dwindling, New Global Indian (http:// newglobalindian.com/nature).

2. Ali, S., Abbas, Z., Rizwan, M., Zaheer, I.E., Yavaş, I.., Ünay, A., Abdel-Daim, M.M., Bin-Jumah, M., Hasanuzzaman, M. and Kalderis, D. (2020). Application of Floating Aquatic Plants in Phytoremediation of Heavy Metals Polluted Water: A Review. Sustainability, 12 (5), 1927. https://doi.org/10.3390/su12051927

3. Ali, S., Ripley, S. D. and Dick, J. H. (1987). Compact handbook of the birds of India and Pakistan.https:// scholar.google.com/scholar_lookup?title=Com pact+handbook+of+the+birds+of+India+an $\mathrm{d}+$ Pakistan\&author=Ali\%2C+Sa\%CC\% 81 lim\&publication_year $=1987$

4. Almuktar, S. A., Abed, S. N., and Scholz, M. (2018). Wetlands for wastewater treatment and subsequent recycling of treated effluent: a review. Environmental Science and Pollution Research, 25(24), 23595-23623. https:// doi.org/10.1007/s11356-018-2629-3

5. Art, I. N. T. for, and Heritage, C. (1998). Delhi's dying water bodies. Indian National Trust for Art and Cultural Heritage New Delhi.

6. Arya, A. K., Bhatt, D., Singh, A., Saini, V., Verma, P., Rathi, R., and Bhatnagar, P. (2019). Diversity and status of migratory and resident wetland birds in Haridwar, Uttarakhand, India. Journal of Applied and Natural Science, 11 (3), 732-737. https://doi.org/10.31018/jans.v11i3.2085

7. Bassi, N., and Kumar, M. D. (2012). Addressing the civic challenges: Perspective on institutional change for sustainable urban water management in India. Environment and Urbanization Asia, 3(1), 165-183.

8. Balasubramanian, R., and Selvaraj, K. N. (2003). Poverty, private property and common pool resource management: The case of irrigation tanks in south India. SANDEE, Kathmandu, Nepal..

9. Bassi, N., Kumar, M. D., Sharma, A., and Pardha-Saradhi, P. (2014). Status of wetlands in India: A review of extent, ecosystem benefits, threats and management strategies. Journal of Hydrology: Regional Studies, 2, 1-19. https:// doi.org/10.1016/j.ejrh.2014.07.001

10.Bates, B., Kundzewicz, Z., and Wu, S. (2008). Climate change and water. Intergovernmental Panel on Climate Change Secretariat.

11.Bennett, M. T., Gong, Y., and Scarpa, R. (2018). Hungry birds and angry farmers: Using choice experiments to assess "eco-compensation" for coastal wetlands protection in China. Ecological Economics, 154, 71-87. 10.1016/ j.ecolecon.2018.07.016

12.Bhatt, D., Sethi, V. K., Sharma, S., Kumar, A., Saini, V., and Singh, A. (2015). Waterbirds of selected wetlands of Uttarakhand. Waterbirds of India, ENVIS WII, 16, 140159.

13.Blackwell, M. S., Hogan, D. V., and Maltby, E. (2002). 15 Wetlands as Regulators of Pollutant Transport. z. (Eds PM Haygarth, SC Jarvis) pp. 321-336.

14.Board, C. P. C. (2009). Status of water supply, wastewater generation and treatment in Class-I cities and Class-II towns of India. Central Pollution Control Board, Government of India New Delhi, India.

15.Board, M. E. A. (2005). Ecosystems and Human WellBeing: Wetlands and Water Synthesis.

16.Boyd, J. and Banzhaf, S. (2007). What are ecosystem services? The need for standardized environmental accounting units. Ecological Economics, 63(2-3), 616-626.

17.Buckton, S. (2007). Managing wetlands for sustainable livelihoods at Koshi Tappu. Danphe, 16(1), 12-13.

18.Butchart, S. H., Walpole, M., Collen, B., Van Strien, A., Scharlemann, J. P., Almond, R. E., Baillie, J. E., Bomhard, B., Brown, C., and Bruno, J. (2010). Global biodiversity: Indicators of recent declines. Science, 328(5982), 11641168.

19.Colette, A. (2013). Case studies on climate change and World Heritage. UNESCO Publishing.

20.Commission, C. W. (2010). Financial aspects of irrigation projects in India. Ministry of Water Resources, Government of India.

21.Costanza, R., De Groot, R., Braat, L., Kubiszewski, I., Fioramonti, L., Sutton, P., Farber, S., and Grasso, M. (2017). Twenty years of ecosystem services: How far have we come and how far do we still need to go? Ecosystem Services, 28, 1-16.

22.Cowardin, L. M., and Golet, F. C. (1979). US Fish and Wildlife Service 1979 wetland classification: A review. In Classification and inventory of the world's wetlands (pp. 139-152). Springer.

23. MoEF (2007). Conservation of wetlands in India: A profile (approach and guidelines)., Government of India New Delhi.

24. Fisheries Division (2017) Hand book of fisheries statistics Department of Animal Husbandry, Dairying and Fisheries, Unit, F. S. (n.d.), Ministry of Agriculture. Government of India, New Delhi.

25.Fisheries Division (2018). Department of Animal Husbandry, Dairying and Fisheries, Ministry of Fisheries, Animal Husbandry \& Dairying, Govt of India, New Delhi.

26.Gardner, R. C., \& Finlayson, M. (2018). Global wetland outlook: State of the world's wetlands and their services to people 2018 . Secretariat of the Ramsar Convention.

27.Ghermandi, A., Van Den Bergh, J. C., Brander, L. M., De Groot, H. L., and Nunes, P. A. (2010). Values of natural and human-made wetlands: A meta-analysis. Water Resources Research, 46(12).

28.Grimmett, R., Inskipp, C., and Inskipp, T. (2016). Birds of the Indian Subcontinent: India, Pakistan, Sri Lanka, Nepal, Bhutan, Bangladesh and the Maldives. Bloomsbury Pub- 
lishing.

29.Han L., Randhir T.O. and Huang, M.S. (2017) Design and assessment of stream-wetland systems for nutrient removal in an urban watershed of China. Water Air Soil Poll 228(4):139-154

30.Hidding, B., Nolet, B. A., De Boer, T., De Vries, P. P., and Klaassen, M. (2010). Above-and below-ground vertebrate herbivory may each favour a different subordinate species in an aquatic plant community. Oecologia, 162(1), 199208.

31.Hagirath, B., Kumar, C., Nauriyal, D. K., Nayak, N. C., Prasad, P. M., Rajgopalan, P., Mishra, P., Trivedi, P. L., Agrawal, A., and Singh, S. P. (2011). Trends in Agriculture and Agricultural Practices in Ganga Basin. An Overview, Tech. rep., Ganga River Basin Managment Plan.

32. Ilyas H, Masih I (2017) The performance of the intensified constructed wetlands for organic matter and nitrogen removal: a review. Journal of Environmental management 198:372-383

33.Jain, C. K., Singhal, D. C., and Sharma, M. K. (2007). Estimating nutrient loadings using chemical mass balance approach. Environmental Monitoring and Assessment, 134(1-3), 385-396.

34.Jain, S. K., Agarwal, P. K., and Singh, V. P. (2007a). Concepts of Water Governance for India. In Hydrology and Water Resources of India (pp. 1155-1189). Springer.

35.Jain, S. K., Agarwal, P. K., and Singh, V. P. (2007b). Hydrology and water resources of India (Vol. 57). Springer Science \& Business Media.

36.Juliano, K., and Simonovic, S. P. (1999). The impact of wetlands on flood control in the Red River Valley of Manitoba. Final Report to International Joint Commission, International Joint Commission, Washington, DC.

37.Kathiresan, K., and Thakur, S. (2008). Mangroves for the future: National strategy and action plan, India. Ministry of Environment and Forests, New Delhi [Revised Draft].

38.Kaur, R., Dhir, G., Kumar, P., Laishram, G., Ningthoujam, D., and Sachdeva, P. (2012). Constructed wetland technology for treating municipal wastewaters. ICAR News, 18 (1), 8-9.

39.Khandekar, N. (2011). Delhi water bodies go under the threats. Hindustan Times.

40.Kickuth, R. (1984). Wurzelraumverfahren in der Praxis. AGRIS, 16(3), 145-153.

41.Kumar, A., Sati, J. P., Tak, P. C. and Alfred, J. R. B. 2005. Handbook on Indian Wetland Birds and their Conservation: i-xxvi; 1- 468 (Published by the Director, Zool. Surv. India).

42.Kumar, M. D., Sivamohan, M. V. K., and Bassi, N. (2013). Technology choices and institutions for improving the economic and livelihood benefits from multiple-use tanks in western Odisha. In Water management, food security and sustainable agriculture in developing economies (pp. 158-183). Routledge.

43.Kumar, R. (2019). Wetlands and waterbirds in Central Asian Flyway: An overview of status, management and conservation priorities for India. Special Issue on Environment, 111-115.

44.Mondal, P., Reichelt-Brushett, A. J., Jonathan, M. P., Sujitha, S. B., and Sarkar, S. K. (2018). Pollution evaluation of total and acid-leachable trace elements in surface sediments of Hooghly River Estuary and Sundarban Mangrove Wetland (India). Environmental Science and Pollution Research, 25(6), 5681-5699.

45.Lal, R. (2008). Carbon sequestration. Philosophical
Transactions of the Royal Society B: Biological Sciences, 363(1492), 815-830.

46.Liu, J., and Diamond, J. (2005). China's environment in a globalizing world. Nature, 435(7046), 1179-1186.

47.McAllister, D. E., Craig, J. F., Davidson, N., Delany, S., and Seddon, M. (2001). Biodiversity impacts of large dams. Background Paper, 1.

48.Millennium Ecosystem Assessment, M. E. A. (2005). Ecosystems and human well-being. Synthesis.

49.Mitsch, William J., and Gosselink, J. G. (2000). Wetlands. John wiley \& sons. Inc., New York, New York.

50.Mitsch, William J., and Jørgensen, S. E. (2007). Ecological engineering and ecosystem restoration. John Wiley \& Sons.

51.MoEFCC (2020a). Ramsar Sites of India - Factsheets. Ministry of Environment, Forest and Climate Change, Government of India

52.MoEFaCC (2020b). List of Ramsar Sites in India, Ministry of Environment, Forest and Climate Change, Wetlands Division, Government of India, New Delhi.

53.Molur, S., Smith, K. G., Daniel, B. A., and Darwall, W. R. T. (2011). The status and distribution of freshwater biodiversity in the Western Ghats, India. Cambridge, UK and Gland, Switzerland: IUCN, and Zoo Outreach Organisation, Coimbatore, India, Viii+ 116pp.

54.NWCP (2009) (National Wetland Conservation Programme). Guidelines for conservation and management of wetlands in India. Conservation and survey division, Ministry of Environment and Forests, Government of India, New Delhi.

55.NPCA (2019). National Plan for Conservation of Aquatic Ecosystems, Ministry of Environment, Forest and Climate Change, Government of India,New Delhi.

56.Palanisami, K., Meinzen-Dick, R., and Giordano, M. (2010). Climate change and water supplies: Options for sustaining tank irrigation potential in India. Economic and Political Weekly, 183-190.

57.Pandey, MM, Tiwari, R., Choubey, A.,. (2015). Population Dynamics in India. International Journal of Scientific \& Engineering Research, (6), 2106-2133.

58.Pant, H. K., Rechcigl, J. E., and Adjei, M. B. (2003). Carbon sequestration in wetlands: Concept and estimation. Food. Agriculture and Environment, 1(2), 308-313.

59.Pant, N., and Verma, R. K. (2010). Tanks in Eastern India: A study in exploration. IWMI.

60.Pattison-Williams, J. K., Pomeroy, J. W., Badiou, P., and Gabor, S. (2018). Wetlands, flood control and ecosystem services in the Smith Creek Drainage Basin: A case study in Saskatchewan, Canada. Ecological economics, 147, 36 $-47$.

61.Prasad, S. N., Ramachandra, T. V., Ahalya, N., Sengupta, T., Kumar, A., Tiwari, A. K., Vijayan, V. S., and Vijayan, L. (2002). Conservation of wetlands of India-a review. Tropical Ecology, 43(1), 173-186.

62.Praveen, J., Jayapal, R., and Pittie, A. (2016). A checklist of the birds of India. Indian BIRDS, 11(5\&6):113-172

63.Grumbine, R. E., and Pandit, M. K. (2013). Threats from India's Himalaya dams. Science, 339(6115), 36-37.

64.Ramachandra, T. V., Kiran, R., Ahalya, N., \& Deepa, R. S. (2002). Status of wetlands in Bangalore. CES Technical Report.

65.Ramachandra, T. V., and Kumar, U. (2008). Wetlands of greater Bangalore, India: Automatic delineation through pattern classifiers. Electronic Green Journal, 26, 2.

66.Ramsar Convention (2018). 'Global Wetland Outlook: State 
of the World's Wetlands and their Services to People.' (Ramsar Convention Secretariat: Gland, Switzerland.)

67.Rai, P. K. (2008). Heavy metal pollution in aquatic ecosystems and its phytoremediation using wetland plants: an Eco sustainable approach. International journal of phytoremediation, 10(2), 133-160.

68.Rebelo, A. J., Morris, C., Meire, P., and Esler, K. J. (2019). Ecosystem services provided by South African palmiet wetlands: A case for investment in strategic water source areas. Ecological Indicators, 101, 71-80.

69.SAC (2011). National wetland atlas. Space application center (SAC). Indian Space Research Organisation (ISRO) Ahmedabad, India .

70.Sala, O. E., Chapin, F. S., Armesto, J. J., Berlow, E., Bloomfield, J., Dirzo, R., Huber-Sanwald, E., Huenneke, L. F., Jackson, R. B., and Kinzig, A. (2000). Global biodiversity scenarios for the year 2100. Science, 287(5459), 1770-1774.

71.Sarkar, J. (2011). Ramsar convention and India. Current Science, 101(10), 1266-1268.

72.Saini, V., Joshi, K., Bhatt, D., Singh, A., and Joshi, R. (2017). Waterbird species distribution between natural and man-made wetland in Himalayan foothills of Uttarakhand, India. Biodiversitas Journal of Biological Diversity, 18(1). 10.13057/biodiv/d180144

73.Secretariat, R. (2013). The list of wetlands of international importance. The Secretariat of the Convention on Wetlands, Gland, Switzerland.

74.Sharma, B. K. (2009a). Composition, abundance and ecology of phytoplankton communities of Loktak Lake, Manipur, India. Journal of Threatened Taxa, 401-410.

75.Sharma, B. K. (2009b). Diversity of rotifers (Rotifera, Eurotatoria) of Loktak lake, Manipur, North-eastern India. Tropical Ecology, 50(2), 277.

76.Singh, A. K., Sathya, M., Verma, S., and Jayakumar, S. (2018). Health risk assessment of heavy metals in crop grains grown on open soils of Kanwar wetland, India. Euro -Mediterranean. Journal for Environmental Integration, 3 (1), 29.

77.Talbot, C. J., Bennett, E. M., Cassell, K., Hanes, D. M.,
Minor, E. C., Paerl, H., Raymond, P. A., Vargas, R., Vidon, P. G., and Wollheim, W. (2018). The impact of flooding on aquatic ecosystem services. Biogeochemistry, 141 (3), 439-461.

78.Tiner, R. W. (1999). A guide to wetland identification, delineation, classification, and mapping. Estados Unidos, CRC Press.

79.Turner, R. K., Van Den Bergh, J. C., Söderqvist, T., Barendregt, A., Van Der Straaten, J., Maltby, E., and Van lerland, E. C. (2000). Ecological-economic analysis of wetlands: Scientific integration for management and policy. Ecological Economics, 35(1), 7-23. https:// doi.org/10.1016/S0921-8009(00)00164-6

80.Verhoeven, J. T., Arheimer, B., Yin, C., and Hefting, M. M. (2006). Regional and global concerns over wetlands and water quality. Trends in Ecology \& Evolution, 21(2), 96-103.

81.Villa, J. A. and Bernal, B. (2018). Carbon sequestration in wetlands, from science to practice: An overview of the biogeochemical process, measurement methods, and policy framework. Ecological Engineering, 114, 115-128. https://doi.org/10.1016/j.ecoleng.2017.06.037

82.Wetlands (Conservation and Management) Rules, 2017, Ministry of Environment, Forest and Climate Change (MoEF\&CC), New Delhi.

83.Wylynko, D. (1999). Prairie wetlands and carbon sequestration. Assessing Sinks under Kyoto Protocol, 12-13.

84.WOOD, K. A., STILLMAN, R. A., CLARKE, R. T., DAUNT, F. \& O'HARE,M. T. (2012). The impact of waterfowl herbivory on plant standing crop: a meta-analysis. Hydrobiologia 686, 157-167.

85.Zedler, J. B., and Kercher, S. (2005). Wetland resources: Status, trends, ecosystem services, and restorability. Annual Review of Environment and Resources., (30), 3974. https://doi.org/10.1146/annurev.energy.30.05 0504.14 4248

86.Zhao, S., Peng, C., Jiang, H., Tian, D., Lei, X., and Zhou, $X$. (2006). Land use change in Asia and the ecological consequences. Ecological Research, 21(6), 890-896. https://doi.org/10.1007/s11284-006-0048-2 